\title{
Effects of apples and specific apple components on the cecal environment of conventional rats: role of apple pectin
}

Tine R Licht ${ }^{1 *}$, Max Hansen², Anders Bergström ${ }^{1}$, Morten Poulsen², Britta N Krath ${ }^{2,3}$, Jaroslaw Markowski ${ }^{4}$, Lars O Dragsted ${ }^{3}$, Andrea Wilcks ${ }^{1}$

\begin{abstract}
Background: Our study was part of the large European project ISAFRUIT aiming to reveal the biological explanations for the epidemiologically well-established health effects of fruits. The objective was to identify effects of apple and apple product consumption on the composition of the cecal microbial community in rats, as well as on a number of cecal parameters, which may be influenced by a changed microbiota.

Results: Principal Component Analysis (PCA) of cecal microbiota profiles obtained by PCR-DGGE targeting bacterial 165 rRNA genes showed an effect of whole apples in a long-term feeding study (14 weeks), while no effects of apple juice, purée or pomace on microbial composition in cecum were observed. Administration of either 0.33 or 3.3\% apple pectin in the diet resulted in considerable changes in the DGGE profiles.

A 2-fold increase in the activity of beta-glucuronidase was observed in animals fed with pectin (7\% in the diet) for four weeks, as compared to control animals $(P<0.01)$. Additionally, the level of butyrate measured in these pectinfed animal was more than double of the corresponding level in control animals $(P<0.01)$. Sequencing revealed that DGGE bands, which were suppressed in pectin-fed rats, represented Gram-negative anaerobic rods belonging to the phylum Bacteroidetes, whereas bands that became more prominent represented mainly Gram-positive anaerobic rods belonging to the phylum Firmicutes, and specific species belonging to the Clostridium Cluster XIVa. Quantitative real-time PCR confirmed a lower amount of given Bacteroidetes species in the pectin-fed rats as well as in the apple-fed rats in the four-week study $(P<0.05)$. Additionally, a more than four-fold increase in the amount of Clostridium coccoides (belonging to Cluster XIVa), as well as of genes encoding butyryl-coenzyme A CoA transferase, which is involved in butyrate production, was detected by quantitative PCR in fecal samples from the pectin-fed animals.

Conclusions: Our findings show that consumption of apple pectin ( $7 \%$ in the diet) increases the population of butyrate- and $\beta$-glucuronidase producing Clostridiales, and decreases the population of specific species within the Bacteroidetes group in the rat gut. Similar changes were not caused by consumption of whole apples, apple juice, purée or pomace.
\end{abstract}

\section{Background}

While the beneficial effects of fruits and vegetables on human health are widely acknowledged due to a number of epidemiological [1] and intervention studies [2,3], the mechanisms behind such effects remain largely unknown. In the integrated European project,

\footnotetext{
* Correspondence: trli@food.dtu.dk

'Department of Microbiology and Risk Assessment, National Food Institute, Technical University of Denmark, Mørkhøj Bygade 19, DK-2860 Søborg, Denmark
}

(c) 2010 Licht et al; licensee BioMed Central Ltd. This is an Open Access article distributed under the terms of the Creative Commons Attribution License (http://creativecommons.org/licenses/by/2.0), which permits unrestricted use, distribution, and reproduction in any medium, provided the original work is properly cited.
ISAFRUIT http://www.isafruit.org, we have set out to uncover effects of apple consumption on a number of biological parameters, as well as to reveal the underlying mechanisms causing these effects. Apples were chosen as study object, since apples are among the types of fruits consumed in highest amounts throughout the European Union.

One of the possible ways for apples and other foods to affect human health parameters is through alteration of the composition and activity of the intestinal microbiota. 
Recent publications have revealed effects of vegetables and fruit products on the bacterial population of the gut $[4,5]$. Large efforts are presently put into studies on the importance of the intestinal microbiota for health. A number of health related targets may be affected by the intestinal microbiota, including the immune system [6], targets related to cancer prevention [7], resistance to infections [8] and obesity [9]. Knowledge about the mechanisms involved in beneficial effects of apples may contribute to the design of novel prebiotic substances.

The main purpose of our study was to identify effects of consumption of apples or apple products on the microbial populations in the rat cecum. Since the cultivable part of the fecal microbiota probably constitutes only $20-50 \%$ of the gut microbes [10], it is important to explore effects on this complex ecosystem by use of molecular fingerprinting methods allowing representation of the non-cultivable bacterial species.

Denaturing Gradient Gel Electrophoresis (DGGE) of PCR-amplified 16S rRNA genes have previously proved very useful for analysis of intestinal bacteria [11-13]. In the present investigation we have used this method for analysis of cecal 16S rRNA fragments amplified with universal primers, targeting the whole bacterial community. Quantitative real-time PCR was used in order to verify changes observed by DGGE. Additionally, we studied selected cecal parameters that could be influenced by a changed microbiota. These included measurements of short-chain fatty acids (SCFA), which have potentially beneficial effects on gut health, as well as of the potentially adverse enzymes synthesized by colonic bacteria, $\beta$-glucosidase (BGL) and $\beta$-glucuronidase (GUS).

\section{Results}

\section{Effect of long-term apple consumption on the rat cecal} environment (Experiment $A$ )

Consumption of $10 \mathrm{~g}$ apples a day for a period of 14 weeks had no effect on cecal $\mathrm{pH}$, relative cecal weight, or production of SCFA (data not shown). Apple consumption led to a small increase (mean \pm standard deviation) in the activity of cecal $\beta$-glucuronidase (GUS) from $5.2 \pm 2.9 \mathrm{U} / \mathrm{g}$ cecal content in 32 control animals to $6.8 \pm 2.9 \mathrm{U} / \mathrm{g}$ in 32 animals fed with $10 \mathrm{~g}$ apples per day $(\mathrm{P}<0.05)$ and an increase in beta-glucosidase (BGL) from $3.5 \pm 1.1$ to $4.6 \pm 1.6 \mathrm{U} / \mathrm{g}$ cecal content $(\mathrm{P}<0.05)$. DMH treatment of 16 animals within each of the groups, ending 6 weeks before euthanization, had no effect on any of these observations.

Principal Component Analysis (PCA) of DGGE profiles containing $16 \mathrm{~S}$ ribosomal genes amplified by universal bacterial primers revealed that apple consumption affected the composition of bacteria in cecal samples (Figure 1). However, it was not possible to explain this
A

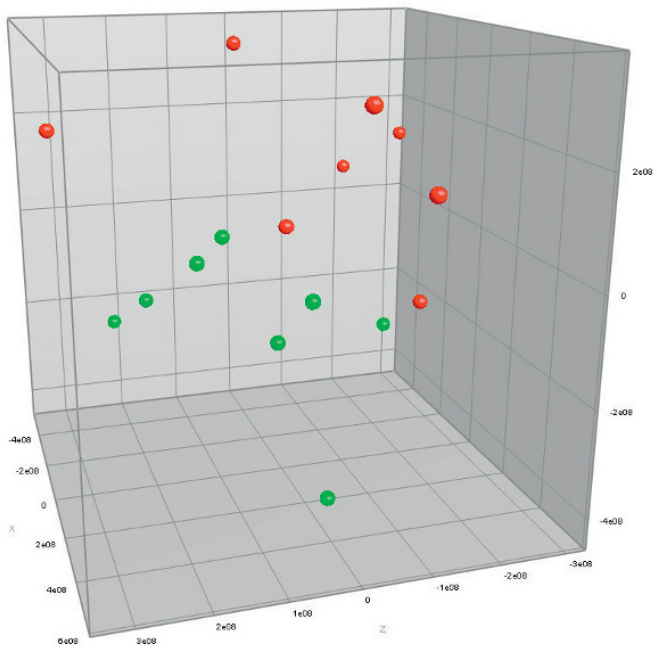

B

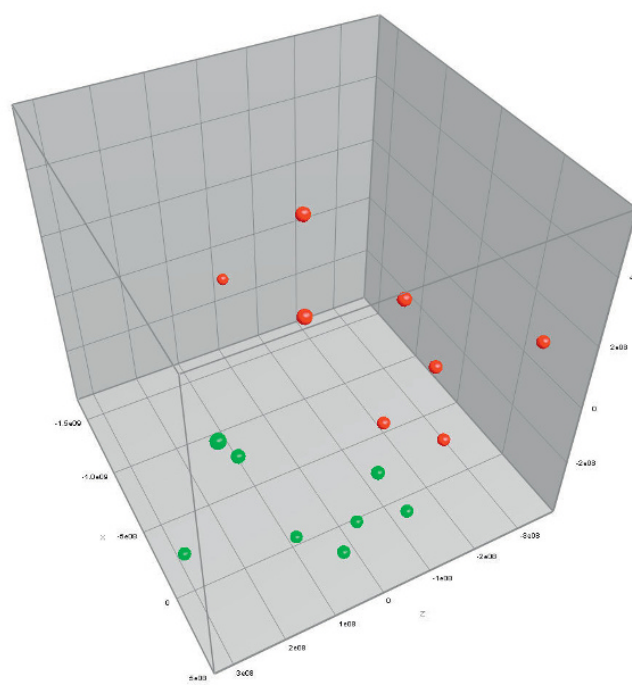

Figure 1 PCA analysis of samples from Experiment A. Principal Component Analysis of DGGE profiles of bacterial rRNA genes present in fecal samples from rat fed with control diet (green) or $10 \mathrm{~g}$ apples a day (red), respectively. A: Uninitiated animals. The amount of variability accounted for by Factor $X$ is $25.0 \%$, by Factor $Y$ 16.2\% and by Factor $Z$ 13.6\%. B: DMH initiated animals. The amount of variability accounted for by Factor $X$ is $31.6 \%$, by Factor $Y 14.3 \%$ and by Factor $Z$ 12.0\%. Comparison of initiated and uninitiated animals by PCA revealed no grouping related to $\mathrm{DMH}$ initiation. 
effect by occurrence of specific bands, and thus not possible to identify specific bacterial species affected by the apple diet.

Effect of long-term consumption of apple purée, pomace, pectin, and juice on the rat cecal environment

\section{(Experiment B)}

To clarify which of the components present in apples that caused the increase in enzymatic activity as well as the changes in cecal bacterial composition, a number of different apple components were tested for 14 weeks in seven groups of 16 initiated animals as described in Materials and Methods. No effect was observed of any of the components tested on cecal $\mathrm{pH}$, cecal weight and GUS activity of the rats (Table 1). The level of cecal BGL activity was lower in the group fed whole apple purée compared to all other groups, including the control group $(\mathrm{P}<0.05)$. None of the components had any effect on the cecal concentrations of acetate and propionate. In the pomace and the $3.3 \%$ pectin groups, there were significant increases in the concentration of butyrate from $14.3 \pm 3.7 \mu \mathrm{mol} / \mathrm{g}$ cecal content in the control group to $27.9 \pm 12.6 \mu \mathrm{mol} / \mathrm{g}$ in the rats fed pomace $(\mathrm{P}<0.01)$ and $20.8 \pm 11.8 \mu \mathrm{mol} / \mathrm{g}$ in the rats fed pectin $(\mathrm{P}<0.05)$ (Table 1).

Comparison of DGGE profiles containing 16S ribosomal genes amplified from cecal contents by universal bacterial primers showed no convincing difference between the control animals and animals fed with either apple purée, pomace, clear or cloudy juice (data not shown). However, animals fed with either $0.33 \%$ or $3.3 \%$ pectin had a clear difference in their composition of cecal bacteria, which was illustrated by PCA (Figure 2).

Effect of short-term consumption of apple and apple pectin on the rat cecal environment (Experiment $\mathrm{C}$ )

To further elucidate the observed effects of whole apples and apple pectin, three groups of eight rats were fed with either control diet, $10 \mathrm{~g}$ apples a day or $7 \%$ pectin for a period of four weeks. There was no significant effect on cecal BGL activity of the rats, but a significant
$(\mathrm{P}<0.01)$ increase in the activity of GUS was observed from $4.1 \pm 1.2 \mathrm{U} / \mathrm{g}$ cecal content in control animals to $10.7 \pm 5.6 \mathrm{U} / \mathrm{g}$ in animals fed with pectin (Table 2). In animals fed $7 \%$ pectin there was an increase $(\mathrm{P}<0.01)$ in the production of cecal butyrate, a decrease in cecal $\mathrm{pH}(\mathrm{P}<0.01)$ and an increase in cecal weight relative to total animal weight $(\mathrm{P}<0.01)$. The apple fed rats also had a significant drop in cecal $\mathrm{pH}(\mathrm{P}<0.05)$ and increase in butyrate $(\mathrm{P}<0.05)$, but no changes in GUS or cecal weight (Table 2).

In the short-term experiment, PCA of the universal DGGE profiles did not reveal an effect of apple consumption (data not shown), as was observed in the long-term trial (Experiment A). However, a marked effect of pectin consumption was observed (Figure 3). Sequencing of bands, which were present on the profiles from pectin-fed animals, but not on the control profiles revealed that these bands represented species belonging to the Gram-negative genus of Anaeroplasma, and the Gram-positive genera Anaerostipes and Roseburia, respectively. Similarly, it was found that bands present on the control profiles but absent on the profiles from pectin-fed rats represented Gram-negative Alistipes and Parabacteroides sp (Figure 3, Table 3).

Quantitative real-time PCR was performed to verify the changes found by DGGE. Bacteroides $16 \mathrm{~S}$ rRNA gene content was significantly lower in both the pectinfed group $(\mathrm{P}=0.03)$ and the apple-fed group $(\mathrm{P}=0.05)$ than in the control group (Figure 4a). With control levels indexed at $100 \%$, levels were $36.6 \pm 17.8 \%$ and $61.4 \pm 20.0 \%$ for the pectin and apple groups, respectively.

There was no statistical significant difference in Lactobacillus 16S rRNA gene content between the three groups $(P=0.07)$, however there was a trend that more lactobacilli were present in the apple-fed group (Figure 4b). Likewise, there was no significant difference in Bifidobacterium 16S rRNA gene content between the three groups $(\mathrm{P}=0.15)$, but a clear trend indicated more

Table 1 Cecal parameters from Experiment B

\begin{tabular}{|c|c|c|c|c|c|c|c|}
\hline Dietary group & Control & Puree & Cloudy juice & $0.33 \%$ pectin & Clear juice & Pomace & $3.3 \%$ pectin \\
\hline $\begin{array}{c}\text { Acetate } \\
(\mu \mathrm{mol} / \mathrm{g} \text { cecal content) }\end{array}$ & $98.0 \pm 26.6$ & $94.7 \pm 30.0$ & $81.5 \pm 40.0$ & $86.7 \pm 39.7$ & $79.3 \pm 27.8$ & $110.9 \pm 29.9$ & $101.9 \pm 36.7$ \\
\hline $\begin{array}{c}\text { Propionate } \\
\text { ( } \mu \mathrm{mol} / \mathrm{g} \text { cecal content) }\end{array}$ & $25.7 \pm 5.8$ & $24.9 \pm 7.4$ & $22.2 \pm 10.1$ & $22.6 \pm 10.0$ & $21.7 \pm 8.7$ & $27.2 \pm 8.0$ & $22.8 \pm 6.0$ \\
\hline $\begin{array}{c}\text { Butyrate } \\
(\mu \mathrm{mol} / \mathrm{g} \text { cecal content) }\end{array}$ & $14.3 \pm 3.7$ & $16.5 \pm 7.2$ & $15.7 \pm 10.4$ & $15.2 \pm 12.5$ & $15.2 \pm 8.0$ & $27.9 \pm 12.6^{* *}$ & $20.8 \pm 11.8^{*}$ \\
\hline Cecal pH & $7.1 \pm 0.1$ & $7.1 \pm 0.1$ & $7.1 \pm 0.3$ & $7.2 \pm 0.3$ & $7.2 \pm 0.1$ & $7.0 \pm 0.1$ & $7.2 \pm 0.4$ \\
\hline $\begin{array}{l}\text { Relative cecum weight } \\
\text { (g/kg b.w.) }\end{array}$ & $7.4 \pm 1.5$ & $9.2 \pm 1.8$ & $8.0 \pm 1.3$ & $7.9 \pm 1.5$ & $8.7 \pm 2.0$ & $8.8 \pm 1.7$ & $8.9 \pm 2.2$ \\
\hline GUS (U/g cecal content) & $5.9 \pm 1.8$ & $6.4 \pm 2.4$ & $7.2 \pm 3.2$ & $7.2 \pm 3.4$ & $6.5 \pm 3.4$ & $6.5 \pm 2.5$ & $7.6 \pm 2.7$ \\
\hline BGL (U/g cecal content) & $5.2 \pm 2.2$ & $3.9 \pm 1.1^{* *}$ & $5.0 \pm 2.6$ & $5.9 \pm 2.5$ & $4.4 \pm 1.1$ & $5.3 \pm 1.2$ & $5.7 \pm 1.9$ \\
\hline
\end{tabular}

The data are averages and standard deviations from 16 animals in each group.

${ }^{*}$ Asterisks indicate a significant difference from the control group; $\mathrm{P}<0.05\left(^{*}\right)$ or $\mathrm{P}<0.01\left(^{* *}\right)$. $\mathrm{U}$ is defined as $\mu \mathrm{mol} / \mathrm{h}$. 
A

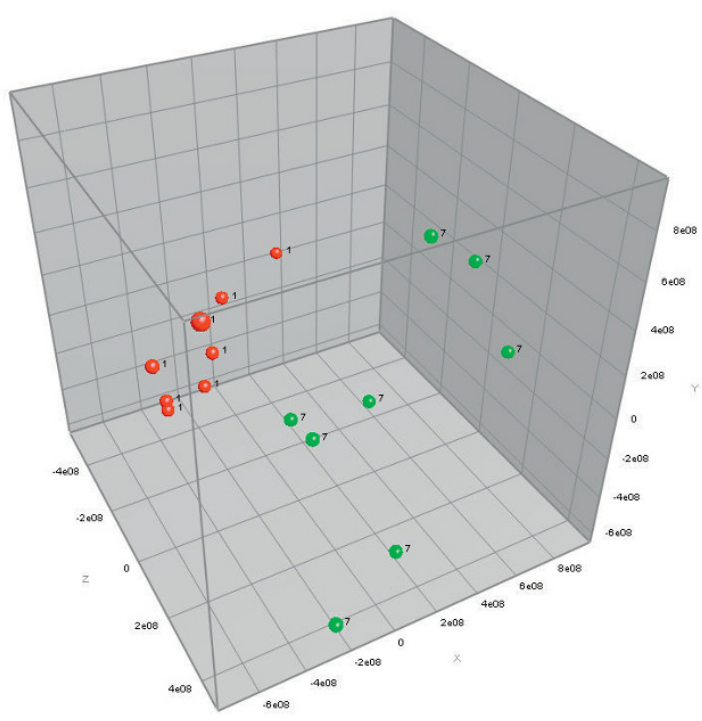

B

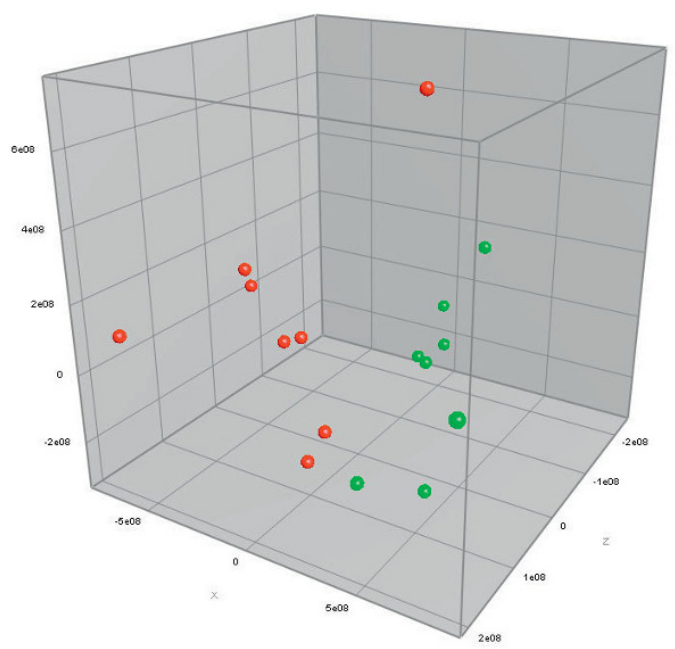

Figure 2 PCA analysis of samples from Experiment B. Principal Component Analysis of DGGE profiles of bacterial rRNA genes present in fecal samples from rat fed with control diet (red) or pectin diet (green), respectively. A: Pectin in diet constituted 3.3\%. The amount of variability accounted for by Factor $X$ is $25.5 \%$, by Factor $Y 19.6 \%$ and by Factor $Z$ 13.8\%. B: Pectin in diet constituted $0.33 \%$. The amount of variability accounted for by Factor $X$ is $36.4 \%$, by Factor $Y 22.1 \%$, and by Factor $Z$ 10.7\%.

Table 2 Cecal parameters from experiment C.

\begin{tabular}{cccc}
\hline Dietary group & Control & $\mathbf{7 \%}$ pectin & $\begin{array}{c}\mathbf{1 0 ~ g} \\
\text { apple }\end{array}$ \\
\hline Propionate $(\mu \mathrm{mol} / \mathrm{g}$ cecal content) & $6.8 \pm 2.3$ & $10.5 \pm 4.4$ & $10.2 \pm 4.1$ \\
Butyrate ( $\mu \mathrm{mol} / \mathrm{g}$ cecal content) & $3.7 \pm 2.2$ & $9.4 \pm 3.1^{* *}$ & $6.7 \pm 4.5^{*}$ \\
Cecal pH & $7.0 \pm 0.1$ & $6.6 \pm 0.2^{* *}$ & $6.8 \pm 0.3^{*}$ \\
Relative cecum weight (g/kg b.w.) & $12.3 \pm$ & $19.0 \pm$ & $15.2 \pm 5.4$ \\
GUS (U/g cecal content) & 1.9 & $5.2^{* *}$ & \\
BGL (U/g cecal content) & $3.5 \pm 0.6$ & $4.9 \pm 1.8$ & $3.8 \pm 1.8$ \\
\hline
\end{tabular}

The data are averages and standard deviations from eight animals in each group.

Bifidobacteria in the pectin-fed group than in the control group (Figure 4c).

Clostridium coccoides 16S rRNA gene contents were significantly higher in the pectin-fed group $(\mathrm{P}<0.001)$ than measured in the control group and in the applefed group (Figure 4d). Contents of C. coccoides rRNA genes in the pectin-fed rats relative to the control rats were $443.7 \pm 14.8 \%$.

Finally, the amount of the butyryl-coenzyme A CoA gene, involved in butyrate production, was significantly higher in the pectin group $(\mathrm{P}<0.0001)$ than in the control group and the apple-fed group (Figure 4e). Levels relative to control were $420 \pm 18.6 \%$ for the pectin group.

\section{Discussion}

This study showed for the first time that intake of whole apples affect the microbial population in the cecum of rats. Effects were observed on the composition of the microbiota after 4 weeks as well as after 14 weeks. In the long-term feeding study the changes could be identified by PCA of the gel patterns produced by DGGE of PCR amplified $16 \mathrm{~S}$ rRNA genes. In the short-term study, PCA did not reveal any major changes, however a statistically significant decrease in the Bacteroides group was observed by qPCR. This indicates that even though short-term consumption introduced minor changes in the intestinal microbiota, long-term consumption was required for these changes to be substantial enough to be detected by the PCA. The observation that long-term consumption of whole apples influenced the rat intestinal microbiota (Figure 1) is consistent with previous studies showing effects of extraction juices, rich in dietary fibers from apples, on gut microbes in rats [5,14]. In contrast to the extraction juices investigated by Sembries and coworkers, the clear and cloudy apple juices applied in the present study contained only very low amounts of dietary fibers and had no effect on the gut microbiota detectable by the methods applied.

Addition of either $0.3,3.3$ or $7.0 \%$ of dry apple pectin to the diet caused overall changes in DGGE profiles of the cecal microbiota, which for the $7 \%$ pectin group was shown to include an increase in species belonging to the 


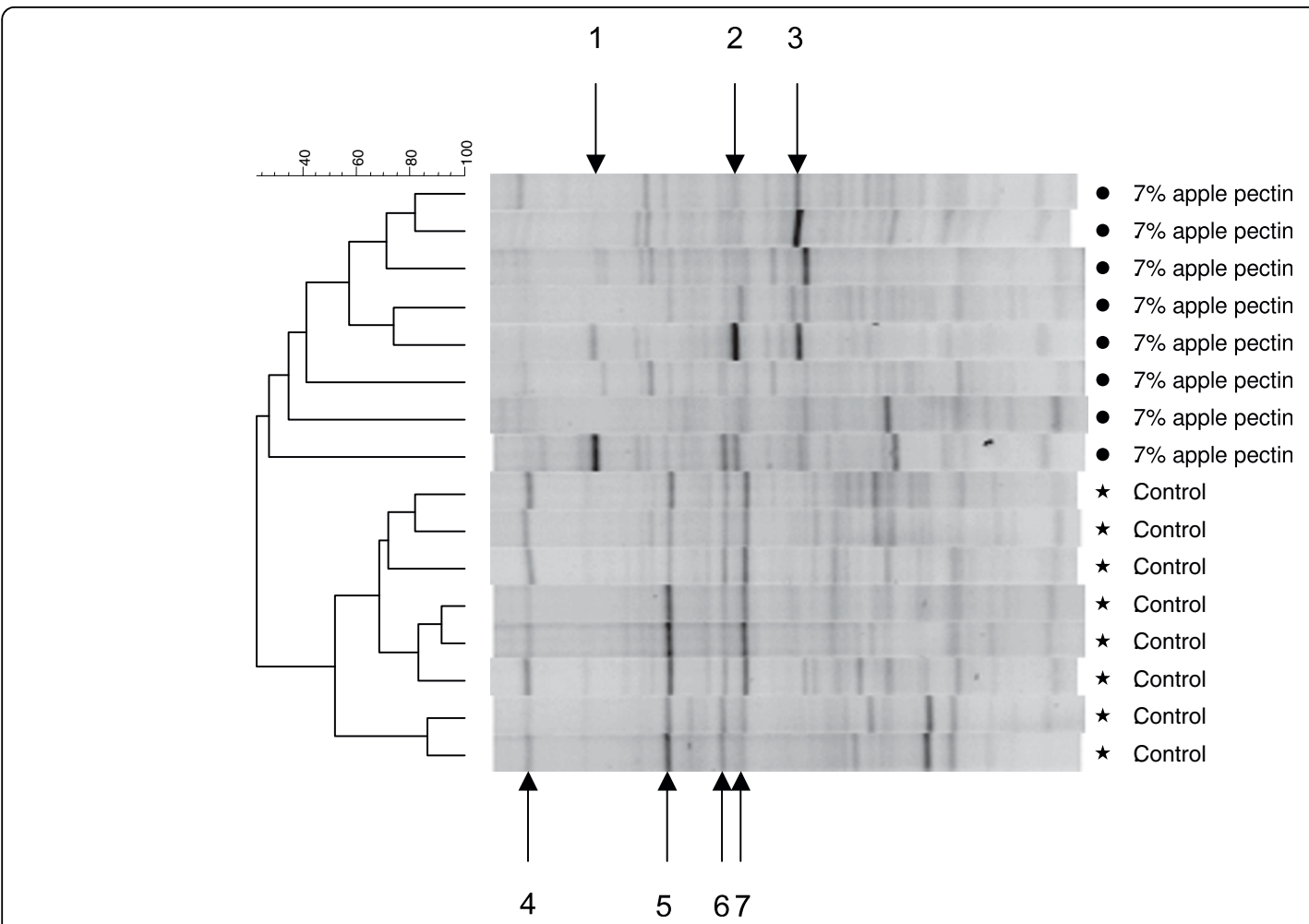

Figure 3 Cluster analysis of samples from Experiment C. Pearson correlation analysis of universal DGGE gel profiles from cecal content of rats fed with either control- or 7\% pectin diet for four weeks. Bands indicated by arrows represents Anaeroplasma (1), Clostridium sp. (2), Clostridiales (3), Bacteroides sp. (4, 6 and 7), and Alistipes (5). Metric scale indicates degree of similarity in percent.

Table 3 Sequenced bands from Experiment $C$, and their closest neighbour in the RDP and GenBank databases (June 2008).

\begin{tabular}{ccccccc}
\hline Band no. & Fragment size/bp & Phylum & Genus & Species & GenBank Acc. no. & Identity (\%) \\
\hline 1 & 172 & Tenericutes & Anaeroplasma & An. bactoclasticum & M25049 & 93 \\
2 & 168 & Firmicutes & Anaerostipes & Uncultured bacterium & AJ418974 & 99 \\
3 & 168 & Firmicutes & Roseburia & Uncultured bacterium & AY975500 & 99 \\
4 & 187 & Bacteroidetes & Parabacteroides & Bacteroides sp. & AF157056 & 100 \\
5 & 179 & Bacteroidetes & Alistipes & Al. massiliensis & AY547271 & 96 \\
6 & 186 & Bacteroidetes & Alistipes & Uncultured bacterium & AJ419011 & 99 \\
7 & 194 & Bacteroidetes & Parabacteroides & Uncultured bacterium & AJ812165 & 98 \\
\hline
\end{tabular}

Gram-negative genus of Anaeroplasma, and the Grampositive genera Anaerostipes and Roseburia, and a decrease in Gram-negative Alistipes and Bacteroides spp (Figure 2 and Figure 3). Previous studies have demonstrated the ability of some Bacteroides species to ferment pectin $[15,16]$ and shown an increase in the Bacteroides population after feeding rats with pectin related products [17]. In vitro fermentation studies have showed an increase in Bacteroides when low methylated pectin was used [18], but other fermentation studies failed to show any effect on this group $[18,19]$. The discrepancies between the studies may be due to differences in pectin used and/or the fact that different Bacteroides populations were studied.
Quantitative real-time PCR (Figure 4a) using a primer set constructed based on the sequenced bands from the DGGE analysis (Figure 3) specified that three-fold less Bacteroides spp were present in samples from pectin-fed rats than in the control. Additionally, a more than fourfold increase in Clostridium coccoides, (corresponding to the Clostridium cluster XIVa) in the pectin-fed animals was showed (Figure 4d). Furthermore, samples from the pectin-fed animals contained four times as many genes encoding the butyryl-coenzyme A CoA transferase as the control samples (Figure 4e). This enzyme is known to be present in bacteria from the Clostridium Cluster $\mathrm{XIVa}$, in strains in the Roseburia-Eubacterium rectale cluster, and in Faecalibacterium prausnitzii, which are 


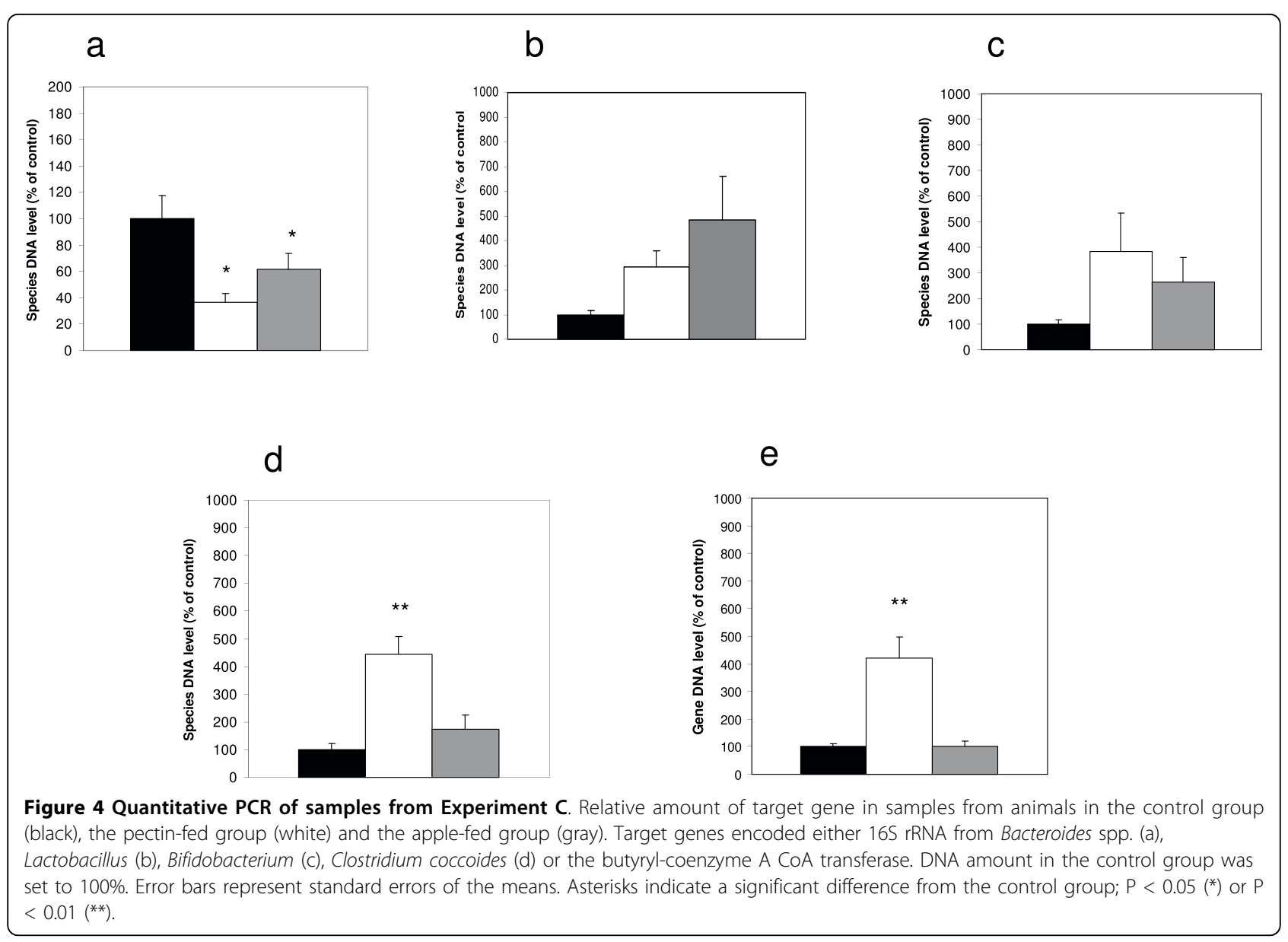

known to be numerically important butyrate-producers in the human gut $[20,21]$.

One previous report showed a decrease in butyrate after feeding rats diet containing $5 \%$ pectin [22], however other studies have shown an increase in butyrate concentration after incubation of fecal slurry with apple pectin [23], or feeding apple pectin to weaning pigs [24]. In consistence with the observed increase in the Clostridum cluster XIva, as well as with another previous report [25], our study revealed a significantly higher amount of butyrate in the animals fed diet containing either $3.3 \%$ or $7 \%$ pectin (Table 1 and Table 2). Butyrate is considered to be particularly beneficial to the gut mucosa because it induces apoptosis in cancer cell lines and functions as fuel for the enterocytes [26,27].

Our results strongly suggest that the observed changes in the microbiota of the apple-fed rats should be attributed mainly to the pectin present in the apples. This is not surprising, since pectin is probably the component of the whole apple most likely to escape digestion and reach the cecal environment. However, it should be noted that the content of pectin in the apples corresponds to only approximately $0.15 \%$ in the diet, and we find it likely that also other components present in the apples contribute in concert to the observed effect on the microbiota. In support of this, it has been reported that apple pectin and a polyphenol-rich apple concentrate had more effect on cecal fermentations and lipid metabolism in rats when fed together than when fed separately [25].

In the present study, we found a significant increase in GUS enzyme activity in cecum of the $7 \%$ pectin-fed rats. This is surprising, since it contradicts a number of other reports showing that dietary pectin reduces GUS activity in the intestinal environment [28-32]. However, in consistence with our observations, Rowland and coworkers [33] reported a significant increase of GUS activity in rats after consumption of a diet containing $5 \%$ pectin, and Bauer and coworkers [34] reported a pectin-induced 10fold increase in fecal GUS activity in pectin-fed rats. Additionally, Dabek et al. [35] reported that GUS activity is preferentially found in members of the Firmicutes phylum, whose populations were increased in the $7 \%$ pectin fed rats. GUS is generally considered as a biomarker for colon cancer development, since it has the potential to activate liver glucuronated toxins and mutagens [36]. However, GUS may in this way also activate beneficial 
compounds, such as liver glucuronated plant polyphenols [37]. Thus, the interaction between dietary pectin, GUS activity and colon carcinogenesis remains to be clarified.

\section{Conclusions}

The reduction of $\mathrm{pH}$, potentially caused by the increased SCFA production, and the increased cecal weight observed in the pectin-fed rats (7\% in the diet) indicate increased cecal fermentation, which is considered beneficial for gut health. The observed increase in butyrate, which is considered beneficial for gut health, correlated with an increase in the Clostridia XVIa cluster that harbors many butyrate producing species. The evidence thus suggests that apples have a health-promoting effect on the rat intestinal microbiota, and that this effect is mainly explained by the presence of pectin in the apples. However, there are lots of cautions to be taken when extrapolating data from animal experiments to humans, and it should be kept in mind that rats metabolize the ingested apple components differently from humans. The data presented here will at a later stage be interpreted in the context of other biological changes recorded during the course of the ISAFRUIT project, which includes also human intervention studies.

\section{Methods}

\section{Animals and housing}

Male Fischer 344 rats (5-8 weeks old) were obtained from Charles River (Sulzfeld, Germany). The animals were housed two by two in standard cages. During the study the temperature was maintained at $22 \pm 1^{\circ} \mathrm{C}$ and relative humidity at $55 \pm 5 \%$, air was changed $8-10$ times per hour, and light was on from 9.00 to 21.00 . Diets and acidified water (adjusted to $\mathrm{pH} 3.05$ by citric acid to prevent growth of microorganisms) were provided ad libitum. During dosing with 1,2-dimethylhydrazine dihydrochloride (DMH) and 1 week thereafter, the animals were kept in flexible film isolators (Isotec 12134, Olac, Oxford, UK). Animal experiments were carried out under the supervision of the Danish National Agency for Protection of Experimental Animals.

\section{Apple products}

The apples and apple products (Shampion cv. supplied by Institute for Pomology, Skierniewice, Poland) used in this study were standardized and all originated from the same harvest. Whole apples were cut in slices and the seeds were removed before serving to the rats. The exact contents of soluble solids and pectin in each of the products were known (Table 4). Obipektin A.G., Bischofszell, Switzerland, kindly provided the apple pectin.

\section{Diets and experimental design}

\section{Experiment $A$}

64 rats were randomized (by bodyweight) in four groups of sixteen animals. After one week (Week 1) of
Table 4 Content of soluble solids and pectin in the different apple fractions

\begin{tabular}{lllll}
\hline Material & $\begin{array}{l}\text { Soluble solids } \\
\text { (\%) }\end{array}$ & Unit & $\begin{array}{l}\text { Total } \\
\text { pectin }\end{array}$ & $\begin{array}{l}\text { Water-soluble } \\
\text { pectin }\end{array}$ \\
\hline Whole Fruit & 12.8 & $\mathrm{~g} / \mathrm{kg}$ & 4.551 & 0.932 \\
Apple purée & 14.5 & $\mathrm{~g} / \mathrm{kg}$ & 4.707 & 2.626 \\
$\begin{array}{l}\text { Cloudy apple } \\
\text { juice }\end{array}$ & 13.0 & $\mathrm{~g} / \mathrm{l}$ & 0.379 & 0.379 \\
$\begin{array}{l}\text { Clear apple } \\
\text { juice }\end{array}$ & 13.5 & $\mathrm{~g} / \mathrm{l}$ & $*$ & $*$ \\
$\begin{array}{l}\text { Pomace dried } \\
\text { Pom }\end{array}$ & - & $\mathrm{g} / \mathrm{kg}$ & 64.9 & 25.7 \\
\hline
\end{tabular}

*Pectic substances are removed during clarification and ultrafiltration

adaptation to a control diet, two groups of animals were fed the same control diet, while two other groups were fed the control diet added $10 \mathrm{~g}$ raw whole apple for a period of 14 weeks until euthanization.

During Week 4-7, one of the control diet-fed groups and one of the apple-fed groups received by gavage 20 $\mathrm{mg} / \mathrm{kg}$ bodyweight of DMH once a week (4 doses in total).

\section{Experiment $B$}

112 rats were randomized (by bodyweight) in seven groups of sixteen animals. After one week (Week 1) of adaptation to a control diet, the rats were fed either (i) control diet, or control diet added (ii) $10 \mathrm{~g}$ apple purée per day, (iii) $8 \mathrm{ml}$ of cloudy apple juice per day, (iv) 8 $\mathrm{ml}$ of clear apple juice per day, (v) $0.5 \mathrm{~g}$ pomace per day, (vi) $0.33 \%$ apple pectin per day or (vii) $3.3 \%$ apple pectin per day for a period of 14 weeks until euthanization.

During Week 4-7 all animals received by gavage 20 $\mathrm{mg} / \mathrm{kg}$ bodyweight of DMH once a week (4 doses in total).

\section{Experiment $C$}

24 rats were randomized (by bodyweight) in three groups of eight animals. After twelve days of adaptation to a control diet, the rats were fed either (i) control diet, (ii) control diet added $10 \mathrm{~g}$ apple per day, or (ii) control diet added $7 \%$ apple pectin for a period of four weeks until euthanization.

Depending on the kind of apple products, the diets were composed to ensure that all animals received the same amount of macro- and micronutrients (Table 5).

\section{Sampling}

Samples of cecal contents were taken from the rats directly after euthanization, and analyzed as described below. In Experiment A and B, DGGE profiling of cecal contents was performed on one animal from each cage, in Experiment $\mathrm{C}$ samples from all animals were analyzed.

A number of other samples were taken to analyze $\mathrm{DMH}$-induced preneoplastic lesions and other biomarkers related to cancer development. However, the data 
Table 5 Composition of the experimental diets

\begin{tabular}{|c|c|c|c|c|c|c|c|c|}
\hline $\begin{array}{l}\text { Ingredients } \\
\text { (g/kg feed) }\end{array}$ & Control & $\begin{array}{c}\text { Whole raw apple } \\
(10 \mathrm{~g} / \mathrm{rat} / \mathrm{day})^{\mathrm{c}}\end{array}$ & $\begin{array}{c}\text { Apple puree } \\
(10 \mathrm{~g} / \text { day/rat })^{\mathrm{c}}\end{array}$ & $\begin{array}{c}\text { Apple juice } \\
(8 \mathrm{ml} / \text { rat/day })^{\mathrm{c}}\end{array}$ & $\begin{array}{l}\text { Apple pomace } \\
(0.5 \mathrm{~g} / \mathrm{rat} / \text { day })\end{array}$ & $\begin{array}{c}\text { Pectin low } \\
(0.33 \%)\end{array}$ & $\begin{array}{c}\text { Pectin medium } \\
(3.3 \%)\end{array}$ & $\begin{array}{c}\text { Pectin high } \\
(7 \%)\end{array}$ \\
\hline Apple pomace & 0 & 0 & 0 & 0 & 35 & 0 & 0 & 0 \\
\hline Apple pectin & 0 & 0 & 0 & 0 & 0 & 3.3 & 33 & 70 \\
\hline $\mathrm{Na}$-caseinate & 200 & 232 & 232 & 232 & 200 & 200 & 200 & 200 \\
\hline Sucrose & 100 & 60 & 0 & 0 & 100 & 100 & 100 & 100 \\
\hline Cornstarch & 456 & 465 & 525 & 497 & 421 & 453 & 423 & 386 \\
\hline Soybean oil & 70 & 80 & 80 & 80 & 70 & 70 & 70 & 70 \\
\hline Corn oil & 80 & 92 & 92 & 92 & 80 & 80 & 80 & 80 \\
\hline Cellulose & 50 & 22 & 22 & 50 & 50 & 50 & 50 & 50 \\
\hline Mineral mixture ${ }^{a}$ & 32 & 37 & 37 & 37 & 32 & 32 & 32 & 32 \\
\hline Vitamin mixture ${ }^{b}$ & 12 & 12 & 12 & 12 & 12 & 12 & 12 & 12 \\
\hline
\end{tabular}

a: Containing in mg/kg diet: $2500 \mathrm{Ca} ; 1600$ P; 3600 K; 300 S; $2500 \mathrm{Na} ; 1500 \mathrm{Cl} ; 600$ Mg; $34 \mathrm{Fe} ; 30 \mathrm{Zn} ; 10$ Mn; 0.20 I; 0.15 Mo; $0.15 \mathrm{Se} ; 2.5 \mathrm{Si} ; 1.0 \mathrm{Cr} ; 1.0 \mathrm{~F} ; 0.5 \mathrm{Ni}$; $0.5 \mathrm{~B} ; 0.1 \mathrm{~B} ; 0.1 \mathrm{~V} ; 0.07 \mathrm{Co}$

b: Containing in mg/kg diet: 5000 (IU) vitamin A; 1000 (IU) vitamin $\mathrm{D}_{3} ; 50$ (IU) vitamin E; 5 thiamin; 6 riboflavin; 8 pyridoxol; 2 folic acid; 0.3 D-biotin; 0.03 vitamin B-12; 20 pantothenate; 2600 cholinhydrogentartrat; 400 inositol; 40 nicotinic acid; 1 phylloquinone; 40 p-aminobenzoic acid; 1000 methionine; 2000 L-cystine.

c: Amount which is given in addition to the diet

obtained from these samples are not reported in the present context.

\section{Analysis of $\mathrm{pH}$ and short chain fatty acid (SCFA) composition in cecal samples}

Measuring of $\mathrm{pH}$ was done directly in the cecal content by use of a $\mathrm{pH}$-meter. Acetate, propionate, and butyrate in cecal contents were analyzed using capillary electrophoresis and indirect UV detection by a method modified from Westergaard et al. [38]. Briefly, approximately $0.1 \mathrm{~g}$ of cecal contents was diluted 10 times in alkaline buffer (0.1 M Tris, pH 8.7 with $100 \mu \mathrm{M}$ malonic acid as internal standard), vortexed for $10 \mathrm{~s}$, centrifuged (14000 $\mathrm{g}, 10 \mathrm{~min}, 4^{\circ} \mathrm{C}$ ) and the supernatant was filtrated using a sterile $0.2 \mu \mathrm{m}$ filter (Minisart). Samples were kept at $-80^{\circ} \mathrm{C}$ until analysis. Prior to analysis the samples were diluted 30 times by running buffer ( $0.2 \mathrm{mM}$ 1,2,4-benzenetricarboxylic acid), $8 \mathrm{mM}$ TRIS and $0.3 \mathrm{mM}$ tetradecyltrimethylammonium bromide, $\mathrm{pH}$ 7.6). The fused silica capillary $(0.75 \mu \mathrm{m}, 80.5 \mathrm{~cm}$ and $72 \mathrm{~cm}$ to detector window) purchased from Agilent (Waldbronn, Germany) was rinsed with $1 \mathrm{M} \mathrm{NaOH}$ before each sequence and pre-treated with water for $0.5 \mathrm{~min}, 0.1 \mathrm{M} \mathrm{NaOH}$ for $1 \mathrm{~min}$ and runningbuffer for $5 \mathrm{~min}$ before each run. Samples were injected by pressure ( $35 \mathrm{mbar}, 2 \mathrm{~s}$ ) and run at $-30 \mathrm{kV}$ for $12 \mathrm{~min}$ on a G1600A 3D Capillary electrophoresis Instrument (Hewlett-Packard, Waldbronn, Germany). All chemicals were purchased from Sigma Aldrich, Steinheim, Germany.

Analysis of $\beta$-glucosidase (BGL) and $\beta$-glucuronidase (GUS) in cecal samples

Samples of cecal content $(0.2 \mathrm{~g})$ were homogenized in 1 $\mathrm{ml}$ phosphate buffered saline (PBS), $0.1 \%$ sodium-azide $\mathrm{pH}$ 7.4, and centrifuged (10000 g, $\left.10 \mathrm{~min}, 4^{\circ} \mathrm{C}\right)$. The supernatant was used to determine the activity of BGLand GUS at $37^{\circ} \mathrm{C}$ on an Automated Roche/Hitachi 912 Analyzer (Roche Diagnostic GmbH, Mannheim, Germany).
BGL was measured by determining the rate of hydrolysis of the substrate $\mathrm{p}$-nitrophenyl- $\beta$-D-glucopyranoside. The amount of p-nitrophenol released was measured at $415 \mathrm{~nm}$ with p-nitrophenol as standard. One unit (U) of enzyme was defined as the amount of enzyme that releases $1 \mu \mathrm{mol}$ of $\mathrm{p}$-nitrophenol per $\mathrm{h}$. GUS was assayed by determining the rate of release of phenolphthalein from phenolphthalein- $\beta$-D-glucuronide at $540 \mathrm{~nm}$ with phenolphthalein as standard. One unit (U) of enzyme was defined as the amount of enzyme that releases $1 \mu \mathrm{mol}$ of phenolphthalein from the substrate phenolphthalein- $\beta$-D-glucuronide, per hour. The specific activity for both enzymes was reported as $\mathrm{U} / \mathrm{g}$ cecum content.

\section{Extraction of bacterial DNA from cecal samples}

For DNA extraction, cecal samples were diluted 1:10 (w/vol) in PBS. DNA was extracted from $2 \mathrm{ml}$ of the $10^{-}$ ${ }^{1}$ dilution using the QIAamp DNA Stool Mini Kit (Qiagen, Hilden, Germany) with a bead-beater step in advance, as described previously [39], and stored in 30 $\mu \mathrm{l}$ autoclaved water at $-20^{\circ} \mathrm{C}$ until use.

\section{PCR amplification for DGGE}

Aliquots $(10 \mu \mathrm{l})$ of purified DNA were applied to the following to give a $50 \mu \mathrm{l}$ PCR reaction mixture: $20 \mu \mathrm{l}$ of 5 PRIME MasterMix (2.5x) (VWR \& Bie \& Berntsen, Herlev, Denmark) and 40 pmol of each of the primers. Primers HDA1-GC/HDA2 [40] targeting 16S rRNA genes from all bacteria were used in a touchdown PCR. Initial denaturation was at $96^{\circ} \mathrm{C}$ for $5 \mathrm{~min}$, amplification was carried out using 20 cycles including denaturation at $94^{\circ} \mathrm{C}$ for $1 \mathrm{~min}$, annealing at $65^{\circ} \mathrm{C}$ for $1 \mathrm{~min}$ decreased by $0.5^{\circ} \mathrm{C}$ for each cycle, and extension at $72^{\circ} \mathrm{C}$ for $1 \mathrm{~min}$. This was followed by additional 5 cycles of denaturation at $94^{\circ} \mathrm{C}$ for $1 \mathrm{~min}$, annealing at $55^{\circ} \mathrm{C}$ for 1 min, extension at $72^{\circ} \mathrm{C}$ for $1 \mathrm{~min}$, and a final extension at $72^{\circ} \mathrm{C}$ for $5 \mathrm{~min}$. 
All PCR reactions were run on a PTC-240 DNA Engine Tetrad 2 Cycler (M) Research, Bio-Rad Laboratories, Copenhagen, Denmark) and the products were verified by gel electrophoresis before proceeding to DGGE analysis.

\section{Analysis of cecal microbiota by denaturing gradient gel electrophoresis (DGGE)}

DGGE was carried out as previously described [41] using a DCodeTM Universal Mutation Detection System instrument and gradient former model 475 according to the manufacturer's instructions (Bio-Rad Labs, Hercules, California). The denaturing gradient was formed with two 9\% acrylamide (acrylamide-bis 37.5:1) stock solutions (Bio-Rad) in $1 \times$ TAE $(20 \mathrm{mM}$ Tris, $10 \mathrm{mM}$ acetate, $0.5 \mathrm{M}$ EDTA, pH 7.4). The gels were made with denaturing gradients ranging from 25 to $65 \%$ for analysis of the amplified 16S rRNA fragments. The 100\% denaturant solution contained $40 \%$ formamide and $7 \mathrm{M}$ urea. PCR product $(13 \mu \mathrm{l})$ were mixed with $3 \mu \mathrm{l}$ loading dye before loading. Gels were run in $1 \times \mathrm{TAE}$ at $60^{\circ} \mathrm{C}$ for $16 \mathrm{hr}$ at $36 \mathrm{~V}, 28 \mathrm{~mA}$, stained with ethidium bromide for $15 \mathrm{~min}$, destained for $20 \mathrm{~min}$, and viewed by UV-B trans illumination at $302 \mathrm{~nm}$. The BioNumerics software, version 4.60 (Applied Maths, Sint-MartensLatem, Belgium) was used for identification of bands and normalization of band patterns from DGGE gels. Pearson correlation and Principal Component Analysis (PCA) based on DGGE pattern profiles were performed using the same software. Subtraction of averages over the characters was included in the PCA analysis.

Excision, cloning and sequencing of selected bands from DGGE gels

Bands of specific interest were excised from DGGE gels with a sterile razor, placed in $40 \mu \mathrm{l}$ sterile water, and incubated at $4^{\circ} \mathrm{C}$ for diffusion of DNA into the water. 33 $\mu \mathrm{l}$ of the sterile water (containing the DNA) was treated with S1 nuclease [42]. For sequencing of bands retrieved from universal DGGE gels, the S1 nuclease treated DNA was used in a PCR with HDA1/2 primers without GCclamp (4 min at $94^{\circ} \mathrm{C}, 20$ cycles consisting of $30 \mathrm{~s}$ at $94^{\circ}$ $\mathrm{C}, 30 \mathrm{~s}$ at $56^{\circ} \mathrm{C}$, and $1 \mathrm{~min}$ at $68^{\circ} \mathrm{C}$, and finally $7 \mathrm{~min}$ at $\left.68^{\circ} \mathrm{C}\right)$. Subsequently the PCR products were directly cloned into $\mathrm{pCR}^{\circ} 4$-TOPO (Invitrogen, Taastrup, Denmark) according to the manufacturer's instructions, and electroporated into electrocompetent $E$. coli TOP10 cells (Invitrogen) with a single pulse $(2500 \mathrm{~V}, 400 \Omega, 25 \mu \mathrm{F})$ by use of a Gene Pulser apparatus (Bio-Rad Laboratories, Richmond, California). Plasmid DNA was isolated from the cells using the Qiagen Mini Spin Prep kit (QIAGEN), and subjected to PCR (HDA1/2-GC) as earlier described. The PCR products were run on a DGGE gel to check the purity and confirm the melting behavior of the excised band. The inserts were sequenced by GATC (Konstanz, Germany) using primers T3 and T7.
The obtained sequences were compared to known sequences in the Ribosomal Database (RDP, Michigan State University, Release 9.61), and aligned using BLAST (bl2seq) and the GenBank database.

\section{Real-time PCR assay conditions}

Real-time PCR was performed on samples from Experiment $C$ on an ABI Prism 7900 HT from Applied Biosystems. The amplification reactions were carried out in a total volume of $20 \mu \mathrm{l}$ containing $10 \mu \mathrm{l}\left(2 \times\right.$ PerfeCTA $^{\text {mm }}$ SYBR $^{\circ}$ Green SuperMix, ROX from Invitrogen, Copenhagen, Denmark), primers (each at $200 \mathrm{nM}$ concentration), $2 \mu$ template DNA, and USB- $\mathrm{H}_{2} \mathrm{O}$ (USB EUROPE CMBH Staufen, Germany) purified for PCR. The amplification program consisted of one cycle at $50^{\circ} \mathrm{C}$ for 2 min; one cycle at $95^{\circ} \mathrm{C}$ for $10 \mathrm{~min} ; 40$ cycles at $95^{\circ} \mathrm{C}$ for $15 \mathrm{sec}$ and $60^{\circ} \mathrm{C}$ for $1 \mathrm{~min}$; and finally one cycle of melting curve analysis for amplicon specificity at $95^{\circ} \mathrm{C}$ for 15 sec, $60^{\circ} \mathrm{C}$ for $20 \mathrm{sec}$ and increasing ramp rate by $2 \%$ until $95^{\circ}$ for $15 \mathrm{sec}$. This program was found by preliminary experiments on target DNA in order to optimize reaction parametres and primer concentrations. The program was efficient and consistent for all primers used as seen by the high PCR efficiencies and correlation coefficients found (Table 6). The amplification products were further subjected to gel electrophoresis in $2 \%$ agarose, followed by ethidium bromide staining to verify amplicon sizes.

The Bacteroides spp. primer set was designed to amplify a segment of the DNA sequence represented by the highly homologous bands 4-7 in Table 3. ClustalW2 http://www. ebi.ac.uk/Tools/clustalw2/index.html was used to align these 4 sequences and NCBI's primer designing tool http://www.ncbi.nlm.nih.gov/tools/primer-blast/ was used to construct the primer set. Finally, the quality of the primer was checked with the Net Primer Software http:// www.premierbiosoft.com/netprimer/index.html.

All results were calculated relatively as ratios of species DNA levels to HDA expression levels in order to correct data for differences in total DNA concentration between individual samples. DNA levels were approximated as $2^{-}$ ${ }^{\mathrm{Ct}}$, where $\mathrm{C}_{\mathrm{t}}$ is the threshold cycle calculated by the ABI software as the PCR cycle, where amplifications signal exceeds the selected threshold value, also set by the software. All samples were calculated as means of duplicate determinations. DNA isolation failed for one animal in the pectin group, hence the three experimental groups were: Control $(\mathrm{N}=8)$, Apple $(\mathrm{N}=8)$, and Pectin $(\mathrm{N}=7)$.

\section{Statistics}

Biomarker endpoints were tested for homogeneity of variance using Levene's test and for normal distribution by visual inspection of residual plots. Log-transformations were performed for data, which did not meet these criteria. The nonparametric Kruskal-Wallis test was used for datasets, which were not normally distributed 
Table 6 Primers used for Real-Time PCR

\begin{tabular}{|c|c|c|c|c|c|c|}
\hline Target gene & Forward primer $\left(5^{\prime}-3^{\prime}\right)$ & Reverse primer $\left(5^{\prime}-3^{\prime}\right)$ & $\begin{array}{l}\text { Product size } \\
\text { (bp) }\end{array}$ & $\begin{array}{c}\text { PCR } \\
\text { Efficiency (\%) }\end{array}$ & $\begin{array}{l}\text { Correlation } \\
\text { coefficient }\left(R^{2}\right)\end{array}$ & Reference \\
\hline $\begin{array}{l}\text { Clostridium } \\
\text { coccoides } 165\end{array}$ & aaa tga cgg tac ctg act aa & $\begin{array}{l}\text { ctt tga gtt tca ttc ttg } \\
\text { cga a }\end{array}$ & 440 & 97,8 & 0,998 & [43] \\
\hline $\begin{array}{l}\text { Bifidobacterium } \\
16 \mathrm{~S} \\
\end{array}$ & cgc gtc ygg tgt gaa ag & ccc cac atc cag cat cca & 244 & 93,0 & 0,995 & [44] \\
\hline Lactobacillus $16 \mathrm{~S}$ & agcagtagggaatcttcca & caccgctacacatggag & 341 & 98,6 & 0,998 & {$[45,46]$} \\
\hline $\begin{array}{l}\text { Bacteroides } \\
\text { spp.165 }\end{array}$ & cgg cga aag tcg gac taa ta & $\begin{array}{l}\text { acg gag tta gcc gat gct } \\
\text { ta }\end{array}$ & 360 & 100,1 & 0,997 & This study \\
\hline $\begin{array}{c}\text { Butyryl-Coenzyme } \\
\text { A }\end{array}$ & $\begin{array}{l}\text { gen gan cat ttc acn tgg aay wsn } \\
\text { tgg cay atg }\end{array}$ & $\begin{array}{l}\text { cct gec ttt gea atr ten } \\
\text { acr aan ge }\end{array}$ & 530 & 97,5 & 0,965 & [21] \\
\hline $\begin{array}{c}\text { V2-V3 16S region } \\
(\text { HDA })^{\mathrm{b}}\end{array}$ & act cct acg gga ggc agc agt & $\begin{array}{l}\text { gta tta ccg cgg ctg ctg } \\
\text { gca c }\end{array}$ & 200 & 113,7 & 0,991 & {$[40]$} \\
\hline
\end{tabular}

${ }^{\mathrm{a}}$ The bacteroides primer set was designed to amplify a segment of the DNA sequence represented by the highly homologous bands $4-7$ in Table 5 . ${ }^{\text {b PCR for the }}$ HDA primer set was run in parallel for each set of primers for all samples.

or did not have homogeneity of variance even after logtransformation. Other data were after ANOVA analyzed by LSM (least square means). These statistical analyses were performed using the SAS Statistical Package, ver. 9.1.3 (SAS Institute Inc., Cary, NC). Statistical analysis of RT-PCR data was performed with SAS JMP version 6.0.2. Data was analyzed by one-way ANOVA followed by a pair-wise multiple comparison of means (Student's t). The significance level was set to $\mathrm{P}=0.05$.

\section{Acknowledgements}

The authors thank Bodil Madsen for excellent technical assistance, and Anne Ørngreen and her staff for professional handling of animals. This work was partly financed by the ISAFRUIT project (FP6-FOOD 016279-2) under the European Sixth Framework Program, and by a grant from the Danish Directorate for Food, Fisheries and Agri Business (3304-FVFP-060696-04) given to LOD.

\section{Author details}

'Department of Microbiology and Risk Assessment, National Food Institute, Technical University of Denmark, Mørkhøj Bygade 19, DK-2860 Søborg, Denmark. ${ }^{2}$ Department of Toxicology and Risk Assessment, National Food Institute, Technical University of Denmark, Mørkhøj Bygade 19, DK-2860 Søborg, Denmark. ${ }^{3}$ Department of Human Nutrition, Faculty of Life Sciences, University of Copenhagen, Rolighedsvej 30, DK-1958 Frederiksberg C, Denmark. ${ }^{4}$ Department of Storage and Processing, Research Institute of Pomology and Floriculture, 96-100 Skierniewice, Poland.

\section{Authors' contributions}

TRL and AW conceived of, designed and coordinated the microbiological investigations, and drafted the paper. MP and LOD conceived of, designed and coordinated the animal experiments. MH carried out the SCFA analyses, BNK carried out the enzyme analyses, AB carried out the RT-PCR measurements, and JM produced and characterized the apple products.

Received: 23 February 2009

Accepted: 20 January 2010 Published: 20 January 2010

\section{References}

1. Key TJ, Fraser GE, Thorogood M, Appleby PN, Beral V, Reeves G, et al: Mortality in vegetarians and nonvegetarians: detailed findings from a collaborative analysis of 5 prospective studies. Am J Clin Nutr 1999, 70:516S-524S

2. Miura K, Greenland P, Stamler J, Liu K, Daviglus ML, Nakagawa H: Relation of vegetable, fruit, and meat intake to 7-year blood pressure change in middle-aged men: the Chicago Western Electric Study. Am J Epidemiol 2004, 159:572-580

3. Steffen $L M$, Kroenke $\mathrm{CH}, \mathrm{Yu}$ X, Pereira MA, Slattery ML, Van $\mathrm{HL}$, et al: Associations of plant food, dairy product, and meat intakes with 15-y incidence of elevated blood pressure in young black and white adults: the Coronary Artery Risk Development in Young Adults (CARDIA) Study. Am J Clin Nutr 2005, 82:1169-1177.

4. Humblot C, Bruneau A, Sutren M, Lhoste EF, Dore J, Andrieux C, et al: Brussels sprouts, inulin and fermented milk alter the faecal microbiota of human microbiota-associated rats as shown by PCR-temporal temperature gradient gel electrophoresis using universal, Lactobacillus and Bifidobacterium 16S rRNA gene primers. Br J Nutr 2005, 93:677-684.

5. Sembries S, Dongowski G, Mehrlander K, Will F, Dietrich H: Physiological effects of extraction juices from apple, grape, and red beet pomaces in rats. J Agric Food Chem 2006, 54:10269-10280.

6. Cunningham-Rundles S, Ahrne S, Bengmark S, Johann-Liang R, Marshall F, Metakis L, et al: Probiotics and immune response. Am J Gastroenterol 2000, 95:S22-S25.

7. Rafter J: Probiotics and colon cancer. Best Pract Res Clin Gastroenterol 2003, 17:849-859.

8. Rastall RA, Gibson GR, Gill HS, Guarner F, Klaenhammer TR, Pot B, et al: Modulation of the microbial ecology of the human colon by probiotics, prebiotics and synbiotics to enhance human health: An overview enabling science and potential applications. FEMS Microbiol Ecol 2005, 52:145-152.

9. Turnbaugh PJ, Ley RE, Mahowald MA, Magrini V, Mardis ER, Gordon Jl: An obesity-associated gut microbiome with increased capacity for energy harvest. Nature 2006, 444:1027-1031.

10. Suau A, Bonnet R, Sutren M, Godon JJ, Gibson GR, Collins MD, et al: Direct analysis of genes encoding $16 \mathrm{~S}$ rRNA from complex communities reveals many novel molecular species within the human gut. App/ Environ Microbiol 1999, 65:4799-4807.

11. Tannock GW: Analysis of the intestinal microflora using molecular methods. Eur J Clin Nutr 2002, 56:S44-S49.

12. Licht TR, Hansen M, Poulsen M, Dragsted LO: Dietary carbohydrate source influences molecular fingerprints of the rat faecal microbiota. BMC Microbiol 2006, 6:98.

13. Zoetendal EG, Collier CT, Koike S, Mackie RI, Gaskins HR: Molecular ecological analysis of the gastrointestinal microbiota: a review. J Nutr 2004, 134:465-472.

14. Sembries S, Dongowski G, Jacobasch G, Mehrlander K, Will F, Dietrich H: Effects of dietary fibre-rich juice colloids from apple pomace extraction juices on intestinal fermentation products and microbiota in rats. $\mathrm{Br} J$ Nutr 2003, 90:607-615.

15. Sirotek K, Slovakova L, Kopecny J, Marounek M: Fermentation of pectin and glucose, and activity of pectin-degrading enzymes in the rabbit caecal bacterium Bacteroides caccae. Lett Appl Microbiol 2004, 38:327-332.

16. Salyers AA, West SE, Vercellotti JR, Wilkins TD: Fermentation of mucins and plant polysaccharides by anaerobic bacteria from the human colon. Appl Environ Microbiol 1977, 34:529-533. 
17. Dongowski G, Lorenz A, Proll J: The degree of methylation influences the degradation of pectin in the intestinal tract of rats and in vitro. $J$ Nutr 2002, 132:1935-1944.

18. Olano-Martin E, Gibson GR, Rastell RA: Comparison of the in vitro bifidogenic properties of pectins and pectic-oligosaccharides. J Appl Microbiol 2002, 93:505-511.

19. Manderson K, Pinart M, Tuohy KM, Grace WE, Hotchkiss AT, Widmer W, et al: In vitro determination of prebiotic properties of oligosaccharides derived from an orange juice manufacturing by-product stream. Appl Environ Microbiol 2005, 71:8383-8389.

20. Pryde SE, Duncan SH, Hold GL, Stewart CS, Flint HJ: The microbiology of butyrate formation in the human colon. FEMS Microbiol Lett 2002, 217:133-139.

21. Louis P, Flint HJ: Development of a semiquantitative degenerate realtime pcr-based assay for estimation of numbers of butyryl-coenzyme $A$ (CoA) CoA transferase genes in complex bacterial samples. Appl Environ Microbiol 2007, 73:2009-2012.

22. Thomsen LL, Roberton AM, Wong J, Lee SP, Tasman-Jones C: Intra-caecal short chain fatty acids are altered by dietary pectin in the rat. Digestion 1984, 29:129-137.

23. Waldecker $M$, Kautenburger $T$, Daumann $H$, Veeriah $S$, Will F, Dietrich $H$, et al: Histone-deacetylase inhibition and butyrate formation: Fecal slurry incubations with apple pectin and apple juice extracts. Nutrition 2008, 24:366-374.

24. Zacharias B, Kerler A, Drochner W: The influence of $5 \%$ and $10 \%$ dietary apple pectin on parameters of fermentation in faeces and caecal digesta of weaning pigs. Arch Anim Nutr 2004, 58:149-156.

25. Aprikian O, Duclos V, Guyot S, Besson C, Manach C, Bernalier A, et al: Apple pectin and a polyphenol-rich apple concentrate are more effective together than separately on cecal fermentations and plasma lipids in rats. J Nutr 2003, 133:1860-1865.

26. Olano-Martin E, Mountzouris KC, Gibson GR, Rastall RA: In vitro fermentability of dextran, oligodextran and maltodextrin by human gut bacteria. Br J Nutr 2000, 83:247-255.

27. Morita A, Tsao D, Kim YS: Effect of sodium butyrate on alkaline phosphatase in HRT-18, a human rectal cancer cell line. Cancer Res 1982, 42:4540-4545

28. Rao CV, Chou D, Simi B, Ku H, Reddy BS: Prevention of colonic aberrant crypt foci and modulation of large bowel microbial activity by dietary coffee fiber, inulin and pectin. Carcinogenesis 1998, 19:1815-1819.

29. Tazawa K, Okami H, Yamashita I, Ohnishi Y, Kobashi K, Fujimaki M: Anticarcinogenic action of apple pectin on fecal enzyme activities and mucosal or portal prostaglandin E2 levels in experimental rat colon carcinogenesis. J Exp Clin Cancer Res 1997, 16:33-38.

30. Ohkami H, Tazawa K, Yamashita I, Shimizu T, Murai K, Kobashi K, et al: Effects of apple pectin on fecal bacterial enzymes in azoxymethaneinduced rat colon carcinogenesis. Jpn J Cancer Res 1995, 86:523-529.

31. Lindop R, Tasman-Jones C, Thomsen LL, Lee SP: Cellulose and pectin alter intestinal beta-glucuronidase (EC 3.2.1.31) in the rat. Br J Nutr 1985, 54:21-26.

32. Shiau SY, Chang GW: Effects of dietary fiber on fecal mucinase and betaglucuronidase activity in rats. J Nutr 1983, 113:138-144.

33. Rowland IR, Mallett AK, Wise A: A comparison of the activity of five microbial enzymes in cecal content from rats, mice, and hamsters, and response to dietary pectin. Toxicol Appl Pharmacol 1983, 69:143-148.

34. Bauer HG, Asp NG, Oste R, Dahlqvist A, Fredlund PE: Effect of dietary fiber on the induction of colorectal tumors and fecal beta-glucuronidase activity in the rat. Cancer Res 1979, 39:3752-3756.

35. Dabek M, McCrae SI, Stevens VJ, Duncan SH, Louis P: Distribution of betaglucosidase and beta-glucuronidase activity and of beta-glucuronidase gene gus in human colonic bacteria. FEMS Microbiol Ecol 2008.

36. Humblot C, Murkovic M, Rigottier-Gois L, Bensaada M, Bouclet A, Andrieux $C$, et al: Beta-glucuronidase in human intestinal microbiota is necessary for the colonic genotoxicity of the food-borne carcinogen 2amino-3-methylimidazo[4,5-f]quinoline in rats. Carcinogenesis 2007, 28:2419-2425

37. Manach C, Scalbert A, Morand C, Remesy C, Jimenez L: Polyphenols: food sources and bioavailability. Am J Clin Nutr 2004, 79:727-747.

38. Westergaard B, Hansen HCB, Borgaard OK: Determination of anions in soil solutions by capillary zone electrophoresis. Analyst 1998, 123:721-724.

39. Leser TD, Lindecrona RH, Jensen TK, Jensen BB, Moller K: Changes in bacterial community structure in the colon of pigs fed different experimental diets and after infection with Brachyspira hyodysenteriae. Appl Environ Microbiol 2000, 66:3290-3296.

40. Walter J, Tannock GW, Tilsala-Timisjarvi A, Rodtong S, Loach DM, Munro K, et al: Detection and identification of gastrointestinal Lactobacillus species by using denaturing gradient gel electrophoresis and speciesspecific PCR primers. Appl Environ Microbiol 2000, 66:297-303.

41. Bernbom N, Norrung B, Saadbye P, Molbak L, Vogensen FK, Licht TR Comparison of methods and animal models commonly used for investigation of fecal microbiota: effects of time, host and gender. J Microbiol Methods 2006, 66:87-95.

42. Tannock GW, Munro K, Bibiloni R, Simon MA, Hargreaves P, Gopal P, et al: Impact of consumption of oligosaccharide-containing biscuits on the fecal microbiota of humans. App/ Environ Microbiol 2004, 70:2129-2136.

43. Matsuki T, Watanabe K, Fujimoto J, Miyamoto Y, Takada T, Matsumoto K, et al: Development of $16 \mathrm{~S}$ rRNA-Gene-Targeted Group-Specific Primers for the Detection and Identification of Predominant Bacteria in Human Feces. Appl Environ Microbiol 2002, 68:5445-5451.

44. Delroisse JM, Boulvin AL, Parmentier I, Dauphin RD, Vandenbol M Portetelle D: Quantification of Bifidobacterium spp. and Lactobacillus spp. in rat fecal samples by real-time PCR. Microbiol Res 2006.

45. Walter J, Hertel C, Tannock GW, Lis CM, Munro K, Hammes WP: Detection of Lactobacillus, Pediococcus, Leuconostoc, and Weissella species in human feces by using group-specific PCR primers and denaturing gradient gel electrophoresis. Appl Environ Microbiol 2001, 67:2578-2585.

46. Heilig HG, Zoetendal EG, Vaughan EE, Marteau P, Akkermans AD, de Vos WM: Molecular diversity of Lactobacillus spp. and other lactic acid bacteria in the human intestine as determined by specific amplification of 16 S ribosomal DNA. Appl Environ Microbiol 2002, 68:114-123.

doi:10.1186/1471-2180-10-13

Cite this article as: Licht et al:: Effects of apples and specific apple components on the cecal environment of conventional rats: role of apple pectin. BMC Microbiology 2010 10:13.

\section{Publish with Bio Med Central and every scientist can read your work free of charge}

"BioMed Central will be the most significant development for disseminating the results of biomedical research in our lifetime. " Sir Paul Nurse, Cancer Research UK

Your research papers will be:

- available free of charge to the entire biomedical community

- peer reviewed and published immediately upon acceptance

- cited in PubMed and archived on PubMed Central

- yours - you keep the copyright
BioMedcentral 